\title{
Creativity and Ecology: A Decade of Contributions for the Design of Sustainable Landscapes (1999-2010)
}

\author{
Paula Gomes da Silva, Linking Landscape, Environment, \\ Agriculture and Food Research Unit/University of Lisbon; University of Algarve, Portugal
}

\begin{abstract}
Ecology has contributed significantly to the evolution of landscape architecture. Currently, ecology continues to have a very significant role in the practice of landscape architecture. Nevertheless, several authors have identified limitations on the knowledge transferal process and on its application by landscape design professionals. This research analysed theoretical criticism on landscape design between 1999-2010, identifying it's legacy in the use of ecological concepts for the development of conceptual and formal design strategies. Were collected and analysed a set of 15 documents on landscape architecture design theory, including books, chapters and essays, mostly related with the landscape urbanism movement. The purpose was to identify the ecological concepts that were used and the way they worked in the design. This study also covered how the use of concepts changed over time. The analysis of the literature recorded the use of 23 ecological concepts and several proposals to its operationalization. The concepts identified fell within two trends: the articulation between form and process; and the adaptive capacity of the design. This paper argues that the theoretical contributions produced between 1999 and 2010 point to meaningful ecological operations from which innovative design approaches, that integrate ecology, can be explored.
\end{abstract}

Keywords: ecology, Creativity, Landscape urbanism, Landscape design

\section{Introduction}

Ecology, field of knowledge of the natural sciences, has been present in landscape architecture since its foundation, and has contributed significantly to the evolution of the profession [1]. Currently, ecology continues to have a very significant role in the practice of landscape architecture, and in the evolution of the theoretical discussions that ground it. In addition to its contributions to scientific knowledge, ecology plays a mediating role in the thinking models that frame the relationship between human beings and nature, and which are embodied in landscape design.

Scientific knowledge is embedded itself in the constructive dimension of landscape designs. Nevertheless, several authors have identified limitations on the knowledge transferal process and on its application by landscape design professionals, such as landscape architects [2; 3]. For ecologists there is a lack of conceptual mechanisms that facilitate the incorporation of ecological knowledge into the production of design solutions [1]. In addition, they report that there is no monitoring process for the actual designs carried out, which evaluates the effectiveness of the implemented solutions $[2 ; 3 ; 4]$. On the other hand, designers have recognised the limitations of a straightforwardly instrumental use of ecology by design. They propose instead that, ecology should play a creative and active part in the production of ideas and conceptual frameworks for design $[5 ; 6 ; 7 ; 8]$.

Recently, several authors acknowledge that in last decades the practice of landscape design has been engaged in the development of new approaches that copy the capacities of continuous adaptation and self-

organization of ecological systems in a creative way [8; 9; 10]. Landscape design is a multidimensional practice that involves social, aesthetic and symbolic aspects, in addition to environmental ones [10]. That means ecology should not only play an instrumental role in landscape design.

The first decade of the twenty-first century (19972010) was extremely productive in the development of possibilities for the integration of the knowledge of several subfields of ecology in landscape design $[8 ; 9 ; 10]$. Under the umbrella of the landscape urbanism movement, innovative hybridization approaches, between natural and technological systems, attempted to introduce, in theory and practice, concepts and models that were being developed in urban ecology, landscape ecology, and systems ecology. Several of these contributions had the clear intention to act as theoretical support for the action [10].

This paper argues that a detailed and structured analysis of this literature and its contribution to the transference of ecological knowledge to design is fundamental. With this purpose this research analysed critical theory, identifying trends in the use of ecological concepts and discussing how these were used for the development of conceptual and formal design strategies. The objectives of this research were: (1) to understand which ecological concepts was fundamental to landscape design and planning; (2) which ecological concepts were used by landscape design; (3) to understand how all these concepts contribute to the development of conceptual and formal strategies. 


\section{Methodology}

Discourse analysis was the core research methodology used here since the research focused on explaining the content and underlying meanings attached to discourse [11]. I chose this method based on the assumption that theoretical discourse and design practices are articulated in dialogic ways; that is, each one reflects aspects of the other. The documents included essays taken from critical collections and articles published in academic journals. This sample was collected in two stages. Firstly, were identified concepts that ecology (landscape ecology and urban ecology) considers relevant for design. Afterwards, was selected and analysed critical literature produced within the field of landscape design theory between 1997-2010 and which focused on the aforementioned ecological concepts.

\section{Ecological Concepts relevant to Landscape Design and Planning}

Ecology has produced an extensive set of theoretical concepts. The research was narrowed by putting in place chronologic and thematic criteria. I chose to consider specifically only the concepts that were developed in relation to contemporary ecology (chronological criteria) and which had as their main focus landscape design applications (thematic criteria). For consistency purposes in relation to the set of bibliography on landscape design theory, I only looked for ecological literature produced in the similar chronological period. Were analysed 4 articles, 3 book chapters and 1 whole book, all written between 1996 and 2013 [2,12-18]. The documents were read in full in order to identify the relevant ecological concepts and principles used.

As result of this task, were identified and grouped concepts related to three aspects of contemporary ecology (Table I). In the first group, were identified concepts linked to the idea of system and nonequilibrium; including Open system, Complex system, Ecosystem. In the second group, were included the concepts and theories related to system openness; such as Scale, Context and Hierarchical theory. In the third group, were integrated the concepts related to the relationship between Process and landscape patterns. Among these, were listed the process; the Patch-corridor-matrix model, developed by landscape ecology; the Spatial pattern; Connectivity; Fragmentation; and the Theory of island biogeography.

\section{Selection of relevant design theory literature}

The selection of relevant design theory bibliography was based on the set of authors/designers identified by Meyer (2008), Steiner (2011) and Thompson (2012). These designers used ecological processes and operations as the conceptual basis for their designs, and support their strategies in contemporary ecological theories. The lower temporal limit of the survey was marked in 1997, which corresponds to the year of the foundation of the landscape urbanism movement [10] The initial set of documents was analysed and extended through the chain sampling method. It's important to note that landscape designers usually don't publish their reflections on design in academic journals which places these documents outside the most important citation databases.

Have been chosen documents which included more than one ecological concept (previously identified), and that discussed the potentialities, possibilities or problems arising from their practical use. The bibliographic collection was limited by implementing the saturation principle. That is, the moment when new ecological concepts were no longer surfacing in critical documents. Was established that a larger number of documents than those actually collected would be detrimental for the purposes of this research.

Based on the criteria already mentioned, was collected a set of 15 reference documents on landscape architecture design theory, including books, chapters and essays mostly published on professional journals (Table II). The selected bibliography was published between 1999 and 2010.

Even in this relatively short period of time, were observed significant changes to ecological concepts and to the ways these were translated into design practice. I studied extensively the selected bibliography, with the purpose of identifying the concepts that were used and the way they worked in the design.

\section{Results: Ecological Concepts on Contemporary Landscape Design Discourse}

The analysis of the 15 documents allowed the identification of 23 ecological concepts, listed in descending order of occurrences (was considered as an occurrence the mere mention in the text and not the number of times the concept was mentioned) (Table III). The concepts were then compared to those collected by the field of ecology research (Table I) and were reorganised into four thematic groups: (I) Complex System; (II) Open system; (III) Relationship Process/structure; (IV) and Dynamics of the system. Group IV was the category that recorded the largest number of concepts (8) and occurrences (47). Group II registered the smallest number of occurrences, 19 only, for the 3 concepts identified. Groups I and III were in the middle.

From all the concepts analysed, Process registered the greatest number of occurrences overall. It was mentioned in 13 of the 15 documents studied ( $87 \%$ ). A few concepts occurred more than $50 \%$ of the time: 
Ecological concepts relevant to landscape design and planning [created by the author]

\begin{tabular}{|c|c|c|c|c|c|c|c|c|}
\hline \# & $\begin{array}{c}\text { Dramstad } \\
\text { and all } \\
1996\end{array}$ & $\begin{array}{c}\text { Pulliam } \\
\& \\
\text { Johnson } \\
2002\end{array}$ & $\begin{array}{l}\text { Karr } \\
2002\end{array}$ & $\begin{array}{c}\text { Johnson } \\
\text { \& al. } \\
2002\end{array}$ & $\begin{array}{l}\text { Pickett } \\
\& \text { al. } \\
2004\end{array}$ & $\begin{array}{l}\text { Hill } \\
2005\end{array}$ & $\begin{array}{l}\text { Lister } \\
2007\end{array}$ & $\begin{array}{c}\text { Ahern } \\
2013\end{array}$ \\
\hline \multicolumn{9}{|l|}{$\begin{array}{l}\text { Systems and non- } \\
\text { equilibrium }\end{array}$} \\
\hline $\begin{array}{l}\text { Open system, } \\
\text { complex system, } \\
\text { ecosystem }\end{array}$ & $\bullet$ & $\bullet$ & $\bullet$ & $\bullet$ & $\bullet$ & $\bullet$ & $\bullet$ & $\bullet$ \\
\hline System's history & & $\bullet$ & & $\bullet$ & & $\bullet$ & $\bullet$ & \\
\hline Multiple steady state & & & & & $\bullet$ & $\bullet$ & $\bullet$ & \\
\hline $\begin{array}{l}\text { Ecological } \\
\text { succession }\end{array}$ & & $\bullet$ & & & $\bullet$ & & & \\
\hline Perturbation & & $\bullet$ & & $\bullet$ & & $\bullet$ & & \\
\hline Resilience & & & $\bullet$ & $\bullet$ & $\bullet$ & $\bullet$ & $\bullet$ & $\bullet$ \\
\hline $\begin{array}{l}\text { Adaptation, Self- } \\
\text { organization, } \\
\text { Emergence }\end{array}$ & & & & $\bullet$ & & & & $\bullet$ \\
\hline Ecological memory & & & & & & & & $\bullet$ \\
\hline \multicolumn{9}{|l|}{ Open systems } \\
\hline Scale & $\bullet$ & $\bullet$ & $\bullet$ & $\bullet$ & & & $\bullet$ & \\
\hline Context & & - & $\bullet$ & $\bullet$ & & & $\bullet$ & \\
\hline Hierarchical theory & & $\bullet$ & & $\bullet$ & & & & \\
\hline \multicolumn{9}{|l|}{ Pattern and process } \\
\hline Process & $\bullet$ & & $\bullet$ & $\bullet$ & $\bullet$ & $\bullet$ & & \\
\hline $\begin{array}{l}\text { Patch-corridor- } \\
\text { matrix model }\end{array}$ & $\bullet$ & & & $\bullet$ & & & & \\
\hline Spatial pattern & $\bullet$ & & $\bullet$ & $\bullet$ & $\bullet$ & $\bullet$ & & \\
\hline $\begin{array}{l}\text { Landscape } \\
\text { heterogeneity }\end{array}$ & & & & & $\bullet$ & $\bullet$ & & \\
\hline $\begin{array}{l}\text { Connectivity, } \\
\text { Fragmentation }\end{array}$ & $\bullet$ & & & $\bullet$ & & & & $\bullet$ \\
\hline Biodiversity & & & & & & & & $\bullet$ \\
\hline Island biogeography & $\bullet$ & $\bullet$ & & & & & & \\
\hline
\end{tabular}

System/Ecosystem (12,80\%), Adaptation / Self organisation (11, 73\%), Complexity / Dynamics (10, $67 \%)$, Context (10 occurrences, $67 \%)$, Openended $(9,60 \%)$ and Emergency (8, $53 \%)$. The groups shared evenly the most frequent concepts, with the exception of group II (System opening), which included the less cited concepts. The concepts less frequently used were Boundaries/Limits (2, $13 \%)$ and Spatial pattern/Heterogeneity (1, $7 \%)$.

Besides concept frequency and categorisation, this study also covered how the use of concepts changed over time. As the number of documents varies according to the year studied, this discrepancy was minimised, by counting one occurrence only, on those years when more than one document was published. For the time period studied (1999-2010), three concepts were mentioned repeatedly: System / Ecosystem (7 / 11), Context (6 / 11) and Process (7 / 11). The concepts grouped in sets I and II did not show any identifiable trend, and occurred nearly every year. The concepts grouped in sets III and IV behaved differently nevertheless. Was detected an incremental tendency in groups III and IV. These concepts became more frequent after 2004. The growing trend in the use of the Relationship Process/structure and the Patch-corridor-matrix model was particularly interesting to landscape design. From 2007 onwards, the use of Resilience emerged as another trend.

\section{Discussing Modes of working Ecological Concepts into Landscape Design: 1999-2010}

\section{Landscape and Design as a Complex Open System}

System/Ecosystem was one of the concepts most frequently used. I believe the steady reoccurrence of this concept throughout the time scale analysed here was due to the fact that it works like a paradigm, encompassing all other concepts. In the selected bibliography, whenever system was cited, it always referred to the notion of complex system [18;23].

System was used to designate either the intervention area or to qualify the design itself. In the first case, the intervention area was understood as a complex reality, described as a field of interactions between natural and social components, and affected by the passage of time $[18 ; 19 ; 21 ; 23 ; 24]$. In the second use, system referred to the reality produced by 
Selected literature [created bu the author]

\begin{tabular}{|l|l|l|}
\hline \multicolumn{1}{|c|}{ Author } & Date & \\
\hline A. Berrizbeitia & 1999 & The Amsterdam Bos: The Modern Public Park and the Construction of Collective Experience \\
\hline S. Marot & 1999 & The reclaiming of site \\
\hline A. Berrizbeitia & 2001 & Scales of Undecidability \\
\hline G. Davoine & 2003 & In Conversation with Michel Desvigne: Intermediate landscapes \\
\hline J. Corner & 2004 & Not unlike life itself \\
\hline J. Corner & 2006 & Terra fluxus \\
\hline J. Czerniak & 2006 & Looking back at landscape urbanism: speculations on site \\
\hline C. Waldheim & 2006 & Landscape as Urbanism \\
\hline J. Corner & 2007 & Proceso \\
\hline G. Hargreaves & 2007 & Large Parks: A Designer's Perspective \\
\hline A. Berrizbeitia & 2007 & Re-Placing process \\
\hline N. Lister & 2007 & Sustainable Large Parks: Ecological designers or Designer Ecology? \\
\hline L. Pollak & 2007 & Matrix landscape: construction of identity in the large park \\
\hline J. Czerniak & 2007 & Legibility and Resilience \\
\hline C. Reed & 2010 & The Agency of Ecology \\
\hline
\end{tabular}

Occurrence of ecological concepts in the documents analyzed [created bu the author]

\begin{tabular}{|l|c|c|c|}
\hline \multicolumn{1}{|c|}{ Ecological concepts } & $\mathrm{N}$ & $\%$ & N Occurrences/group \\
\hline I. Complex system & & & \\
\hline System/Ecosystem & 12 & 80 & \\
\hline Complexity/Dynamics & 10 & 67 & \\
\hline Uncertainty/ Indeterminacy & 6 & 40 & \\
\hline II. Open system & & & \\
\hline Context & 10 & 67 & \\
\hline Scale & 7 & 47 & \\
\hline Boundaries/Limits & 2 & 13 & \\
\hline III. Relationship Structure/process & & & \\
\hline Process & 13 & 87 & \\
\hline Open-ended & 9 & 60 & \\
\hline Patch-corridor-matrix model & 7 & 47 & \\
\hline Relationship Structure/process & 4 & 27 & \\
\hline Spatial pattern / Heterogeneity & 1 & 7 & \\
\hline IV. System dynamics & & & \\
\hline Adaptation/Self-organization & 11 & 73 & \\
\hline Emergency & 8 & 53 & \\
\hline Autopiesis/Structure and organization & 7 & 47 & \\
\hline Ecological succession & 5 & 33 & \\
\hline Diversity & 4 & 27 & \\
\hline Systems' history & 4 & 27 & \\
\hline Disturbance & 4 & 27 & \\
\hline Resilience & 4 & 27 & \\
\hline
\end{tabular}

the act of designing (the design). The analysed literature argue that contemporary design must take on the traits of a complex open system. That means, contemporary design must be able to deal with complexity and uncertainty. It must be proactive. Design should integrate from the outset diverse ecological and social components. It should also be capable of integrate future changes (e.g. ecological conditions, spatial and formal organisation, program of activities) [19; 25].

Most authors abandoned therefore the idea of design as a finished object $[18 ; 19 ; 21,24-29]$. This new understanding demanded novel approaches to the design. The drawing of shapes (configurations) was replaced by the design of processes [29]. The remaining concepts identified were related to characteristics and/or the properties of a complex open system.

\section{Connecting process to structure - processes generate forms}

The concept of Process (group II) was the most frequently cited. In the field of systems ecology, process is core, which explained its dominance here. Due to this change of perspective, design became centred on the mechanisms of landscape functioning and on the relationships between the elements, rather than on the elements themselves $[19 ; 21]$. 
Occurrence of ecological concepts by analyzed literature [created by the author]

TABLE 4

\begin{tabular}{|c|c|c|c|c|c|c|c|c|c|c|c|c|c|c|c|c|}
\hline Ecological concepts & 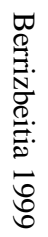 & $\begin{array}{l}3 \\
30 \\
0 \\
0 \\
0 \\
0\end{array}$ & 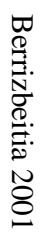 & 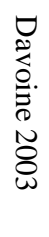 & 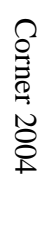 & 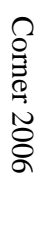 & 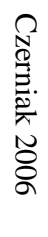 & 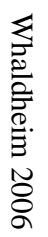 & 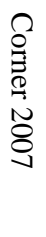 & 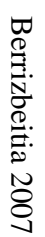 & 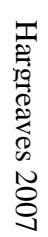 & 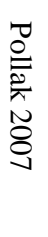 & 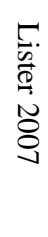 & 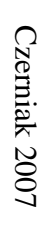 & $\begin{array}{l}2 \\
\mathbb{0} \\
\mathbb{2} \\
N \\
0 \\
0 \\
0\end{array}$ & 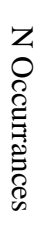 \\
\hline \multicolumn{17}{|l|}{ I. Complex system } \\
\hline $\begin{array}{l}\text { System / } \\
\text { Ecosystem }\end{array}$ & & 1 & 1 & 1 & 1 & 1 & 1 & 1 & 1 & 1 & & & 1 & 1 & 1 & 12 \\
\hline $\begin{array}{l}\text { Complexity / } \\
\text { Dynamics }\end{array}$ & & 1 & 1 & & 1 & & & & 1 & 1 & 1 & 1 & 1 & 1 & 1 & 10 \\
\hline $\begin{array}{l}\text { Uncertainty / } \\
\text { Indeterminacy }\end{array}$ & & & 1 & 1 & 1 & 1 & & 1 & & & & & 1 & & & 6 \\
\hline \multicolumn{17}{|l|}{ II. Open system } \\
\hline Context & & 1 & 1 & 1 & 1 & 1 & 1 & & & 1 & 1 & 1 & 1 & & & 10 \\
\hline Scale & & & & & & 1 & 1 & & & 1 & 1 & 1 & 1 & 1 & & 7 \\
\hline $\begin{array}{l}\text { Boundaries / } \\
\text { Limits }\end{array}$ & & 1 & & & & & & & & & & 1 & & & & 2 \\
\hline \multicolumn{17}{|l|}{$\begin{array}{l}\text { III. Relationship } \\
\text { Structure / process }\end{array}$} \\
\hline Process & 1 & 1 & 1 & 1 & 1 & 1 & 1 & 1 & 1 & 1 & 1 & 1 & & & 1 & 13 \\
\hline Open-ended & 1 & 1 & & & 1 & 1 & & 1 & & 1 & 1 & & & 1 & 1 & 9 \\
\hline $\begin{array}{l}\text { Patch-corridor-matrix } \\
\text { model }\end{array}$ & & & & & 1 & 1 & & & 1 & 1 & 1 & 1 & & 1 & & 7 \\
\hline $\begin{array}{l}\text { Relationship } \\
\text { Structure / } \\
\text { process }\end{array}$ & & & & & 1 & 1 & 1 & & 1 & & & & & & & 4 \\
\hline $\begin{array}{l}\text { Spatial pattern / } \\
\text { Heterogeneity }\end{array}$ & & & & & & & & & & & & 1 & & & & 1 \\
\hline \multicolumn{17}{|l|}{ IV. System dynamics } \\
\hline $\begin{array}{l}\text { Adaptation / } \\
\text { Self-organization }\end{array}$ & & & 1 & & 1 & 1 & & 1 & 1 & 1 & 1 & 1 & 1 & 1 & 1 & 11 \\
\hline Emergency & & & 1 & & 1 & & & & 1 & 1 & 1 & & 1 & 1 & 1 & 8 \\
\hline $\begin{array}{l}\text { Autopiesis / } \\
\text { Structure and } \\
\text { organization }\end{array}$ & & & 1 & 1 & 1 & 1 & & & 1 & 1 & 1 & & & & & 7 \\
\hline Ecological succession & 1 & & & & 1 & & & 1 & & 1 & & & & & 1 & 5 \\
\hline Diversity & & & & & & & & & 1 & & 1 & & 1 & 1 & & 4 \\
\hline Systems' history & & 1 & & & & & & & & 1 & 1 & & 1 & & & 4 \\
\hline Disturbance & & & & & & & & & & 1 & & 1 & 1 & 1 & & 4 \\
\hline Resilience & & & & & 1 & & & & & & & 1 & 1 & 1 & & 4 \\
\hline
\end{tabular}


When the focus on process began, the form and composition were given secondary roles. A design was to be conceived as a process, and its aesthetic value laid, not in its appearance, but in the transformative acts it favoured $[31 ; 32 ; 35]$. The rejection of formal composition posed nevertheless practical problems for the professions, like landscape architecture, that use form as a tool for design. It was only after some reflection that the solution to this problem emerged from the theory of Landscape Ecology. According to this discipline, landscape could be described using the same three elements that make up any system: structure; function and change [35]. Other core principles of landscape ecology included interactions between landscape patterns and their processes $[3 ; 31 ; 32]$. From 2004, some of the analysed documents argue that this interdependence is crucial to landscape design, recognizing that any change to the organisation and spatial configuration of a landscape will necessarily impact (positively or negatively) its processes $[21 ; 33]$.

The emphasis that landscape ecology puts on process contrasts with its observed low occurrence in our selected bibliography. The change occurred in 2004 when concepts and models started to be frequently referenced. From this date onwards, were found recurrent mentions to the relationship between Structure/Process $[21 ; 22 ; 25 ; 34]$ and the Patchcorridor-matrix model [19, 21-23; 28; 33]. I believe this change has signalled a greater openness by designers to the contributions of landscape ecology.

The relationship between configuration (structure) and process allowed design to reject considering one over the other. Hence, the dialectical relationship between these two components of the landscape would prevail over the understanding which considered them as dichotomies [21;22]. The compatibility between process and design was made easier by the idea that the physical configuration shapes and materials - supported the flow of the process. The reciprocity of this relationship indicated that, in addition to forms influencing processes, processes generated forms $[21 ; 22 ; 34]$. Thus, it became possible for landscape design to reconcile the attention given to process alongside configuration by asking the following two questions: What configurations sustain the processes that the design wants to promote? What spatial organisations (what configurations) are generated by processes?

\section{Design is an Adaptive System}

One of the most commonly discussed notions in the literature was the ability for Adaptation/Selforganisation, typical of living systems. From the analysed bibliography I argue that the discussion of adaptation (self-organisation) was centred around two ideas. First was recognized that the design should have the capacity to evolve and adapt to changes that may occur on ecology, society, economy, politics, or other $[7 ; 13,24-30 ; 32 ; 34 ; 39]$. Second the design should be able to produce its own material and programmatic components (e.g. habitats, vegetation, soil, or programmatic events) $[19 ; 26 ; 28 ; 29]$. Were identified three ecological concepts relevant to this discussion: Disturbance, Emergency and Resilience.

Disturbance is a key component of adaptation. It is the way a system reacts to disturbance that triggers the self-organising mechanism [35]. While disturbance was not one of the most mentioned concepts in the bibliography, it was mentioned by some of the authors. Discussions emphasised the need to improve, from the very beginning, the capacity of a design to integrate evolution and changes in response to disturbance, by establishing key elements and processes $[18 ; 19 ; 23 ; 33]$. Disturbance could be read here as a positive component; as long as it was associated with a strategic vision and a flexible proposal capable of absorbing it, even if partially. On the other hand, recurrent disturbances, identified in the analysis stage (e.g. floods, fires or lack of financing for maintenance work), could be incorporated into the design and even used as ways to improve a proposal with novelty and surprise [6].

Emergency is a fundamental property of living systems as it relates to the process of adaptation. Despite this, it is not frequently mentioned or commented on. It may be that designers' limited knowledge of the role that emergency plays in the adaptive cycle explains this small footprint. As a system evolves, emergency can be found in ecosystems whenever new species, communities, habitats and ecological processes of increasing complexity emerge [36]. In socio-ecological systems, emergency leads to the appearance of new institutions, ideas and / or policies [37]. In the literature reviewed, emergency's influence was positively perceived $[21 ; 22 ; 28 ; 29]$. It was claimed that designs should be designed as facilitators of ecological and programmatic emergency processes $[19 ; 20 ; 23]$. Emergency was most commonly mentioned here in relation to ecology. In this context, the capacity of self-production was explored through the stimulation of ecological succession, leading to the appearance of new habitats, species of vegetation and fauna, as well as the improvement of existing pedological or hydrological resources $[18 ; 19 ; 20 ; 28]$. One advantage of emergency is the reduction of implementation costs. The disadvantage is that the construction process would be more time-consuming. This could become a positive aspect, if it allowed a greater community involvement as the design developed. Another favourable outcome would be the possibility of monitoring the results, and the subsequent incorporation of this knowledge in the process of design implementation [7, 24-2; 33; 39]. 
Finally, Resilience is a concept that has become more frequent at the end of the analysed period and is currently recognised as an important component of the adaptation process of complex systems [8]. It is related to the persistence capacity of a system, which has the ability to adapt itself without losing any of its essential characteristics [39].

In landscape design, resilience demands a balance between the potential for change and the need for persist [8]. Change is an essential condition for the survival of a design. On the other hand, continuity ensures the preservation of a design's identity $[19 ; 20 ; 21]$. The analysed literature also highlights this concern and proposed solutions for it. In order to resolve this apparent contradiction, Berrizbeitia [20] drew on the differentiation between structure and organisation developed by Autopoietic Theory. According to Autopoietic Theory, systems can be organisationally closed (identity) but structurally opened (renewal). When applied to the design, this means the design would consider structure and organisation separately $[20 ; 21]$. The analysed literature propose two design strategies to put this idea into practice. One way of doing this would be to design a recognizable formal configuration (circle, rectangle, square, grid), which, in articulation with the paths, would ensure the most enduring aspect of the design. The areas not included in this component would be freer to separately pursue programmatic and material evolution. A second way of introducing design flexibility would be to create several structures - relatively autonomous - so that changing one of them would not spur changes to all (layering) [23].

\section{Conclusion}

This research verified that the critical literature produced between 1999-2010 recorded and reflected about important innovations that were being experimented in landscape architecture of those days in relation to the transference of ecological knowledge to design.

The 23 ecological concepts recorded, allowed to conclude that designers were reasonably up to date. The majority of concepts highlighted by ecology theory were also found in the criticism and practice of landscape design. Also, there were no significant inconsistencies observed, when comparing the way in which concepts were used by design theory and ecology.

The analysed authors understand project as a complex open system. Accepting this idea was fundamental, as it allowed for a connection between ecological sciences and landscape design. The former offer content and procedures, which were used by the latter in the development of design strategies. The concepts identified fell within two trends: the articulation between form and process; and the adaptive capacity of the design. Regarding contributions made by ecological disciplines, the three fields of research most prominent were systems ecology, landscape ecology and urban ecology.

Although almost 10 years have passed on these contributions, it can be affirmed that the ideas underlying the discourses analysed are still up to date and their potential has not yet been fully explored. On this last idea the research noted that the use of concepts still falls short, as each of them could contribute more creatively and generate a greater articulation between ecology and landscape design. Was also found that no aspects recorded related to the monitoring of successes or problems arising from the implemented design strategies.

It's true that, as argued by ecology studies, is still difficult to transfer the scientific knowledge produced for the design and planning. Landscape architecture is not a science and the best way to access scientific and adequate knowledge is promoting the integration of ecologists into design teams, like some of the projects described in the literature have done. This allows designers to apply the scientific developments produced in science to landscape design, and also enables ecologists to learn from the design, by monitoring the actions taken.

Ideas to reformulate the relationship between ecological and social systems are increasingly needed to face the challenges posed by climate change, biodiversity loss and key resources scarcity. This paper has shown that the theoretical contributions produced between 1999 and 2010 are still relevant nowadays. It also argue that they should be further explored by landscape architects and ecologists, since they point to meaningful ecological operations from which innovative landscape design approaches, that integrate ecology, can be explored.

\section{Acknowledgements}

I gratefully acknowledge the financial support from Portuguese Foundation for Science and Technology through the Research Centre LEAF (Linking, Landscape, Environment, Agriculture and Food) UID/AGR/04129/2013. I also thank the peer review's comments on an earlier version of this article.

\section{References}

1. Ecology and Design: Frameworks for Learning. Johnson, B. R., Hill, K., (eds.) Washington: Island Press, 2002. 530 pp. ISBN 1-55963-813-3

2. Ahern, J. Urban landscape sustainability and resilience: the promise and challenges of integrating ecology with urban planning and design. Landscape Ecology, 2013, Vol. 28(6), p. 1203-1212. doi:10.1007/s10980-012-9799-z 
3. Nassauer, J. I., Opdam, P. Design in science: extending the landscape ecology paradigm. Landscape Ecology, 2008, Vol. 23(6), p. 633-644. doi: 10.1007/s10980-008-9226-7

4. Nassauer, J. I. Landscape as medium and method for synthesis in urban ecological design. Landscape and Urban Planning, 2012, Vol. 106(3), p. 221-229. https://doi.org/10.1016/j.landurbplan.2012.03.014

5. Corner, J. Ecology and landscape as agents of creativity. Ecological design and planning. G. F. Thompson, Fr. R. Steiner (Eds.) New York: J. Wiley \& Sons, 1997, p. 80-108. ISBN-13: 978-0471156147

6. Meyer, E. K. Sustaining beauty: The performance of appearance. Journal of Landscape Architecture, 2008, Vol. Spring, p. 6-23. https://doi.org/10.1080/18626033.2008.9723392

7. Reed, C., Lister, N.-M. Projective ecologies. New York: Harvard University Graduate School of Design and Actar Publishers, 2014. 378 pp. ISBN 978-1940-291-12-3

8. Dramstad, W. E., Olson, J. D., Forman, R. T. T. Landscape ecology principles in landscape architecture and land-use planning. 80 pp. Washington: Island Press, 1996. ISBN 1-55963-514-2

9. Pulliam, H. R. Ecology's new paradigm: What does it offer designers and planners? Ecology and Design: Frameworks for Learning. Johnson, B. R., Hill, K., (eds.) Washington: Island Press, 2002, p. 51-84. ISBN 1-55963-813-3

10. Karr, J. What from ecology is relevant to design and planning? Ecology and Design: Frameworks for Learning. Johnson, B. R., Hill, K., (eds.) Washington: Island Press, 2002, p. 133-171. ISBN 1-55963-813-3

11. Johnson, B. J., Silbernagel, J., Hostetler, M., et. al. The Nature of Dialogue and The Dialogue of Nature: Designers and Ecologists in Collaboration. Ecology and Design: Frameworks for Learning. Johnson, B. R., Hill, K., (eds.) Washington: Island Press, 2002, p. 305-356. ISBN 1-55963-813-3

12. Pickett, S. T. A., Cadenasso, M. L., Grove, J. M. Resilient cities: meaning, models, and metaphor for integrating the ecological, socio-economic, and planning realms. Landscape and Urban Planning, 2004, Vol. 69(4), p. 369-384. https://doi.org/10.1016/j.landurbplan.2003.10.035.

13. Hill, K. Shifting sites. Site Matters: Design Concepts, Histories, and Strategies, Burns, C., J., Kahn, A. (eds.). New York and London: Routledge, 2005, p. 131-155. ISBN 978-0415949767

14. Lister, N.-M. Sustainable large parks: Ecological design or designer ecology? Large parks, J. Czerniak, G. Hargreaves (eds.). New York: Princeton Architectural Press, 2007, p. 35-57. ISBN 1-56898-624-6

15. Berrizbeitia, A. Re-placing process. Large parks, J. Czerniak, G. Hargreaves (eds.). New York: Princeton Architectural Press, 2007, p. 175-197. ISBN 1-56898-624-6

16. Berrizbeitia, A. Scales of undecidability. CASE: Downsview Park Toronto, Czerniak, J. (ed.), Munich; New York: Prestel Verlag; Harvard University, Graduate School of Design, 2001, p. 116-125. ISBN: 3791325361

17. Corner, J. Not unlike life itself: Landscape strategy now. Harvard Design Magazine: Rising Ambitions, Expanding Terrain: Realism and Utopianism, F/W 2004, no. 21, p. 1-3. ISSN 1093-4421

18. Corner, J. Proceso. Landscape +: 100 palabras para habitarlo (Landscape +100 Words to Inhabitat It), D. Colafranceschi (ed.). Barcelona: Editorial Gustavo Gili, 2007, p. 157-158. ISBN 978-842522-024-1

19. Czerniak, J. Legibility and resilience. Large parks, J. Czerniak, G. Hargreaves (eds.). New York: Princeton Architectural Press, 2007, p. 215-251. ISBN 1-56898-624-6

20. Waldheim, C. Landscape as urbanism. Landscape Urbanism: A Manual for the Machinic Landscape, M. Mostafavi, C. Najle (eds.). London: Architectural Association, 2003, p. 35-53. ISBN 1-90290-230-0

21. Corner, J. Terra fluxus. The Landscape Urbanism Reader, C. Waldheim (ed.). New York: Princeton Architectural Press, 2006, p. 23-33. ISBN: 978-1568984391

22. Berrizbeitia, A. The Amsterdam Bos: The modern public park and the construction of collective experience. Recovering Landscape: Essays in Contemporary Landscape Architecture, J. Corner (ed.). New York: Princeton Architectural Press, 1999, p. 188-203. ISBN 978-1568981796

23. Marot, S. The reclaiming of sites. Recovering Landscape: Essays in Contemporary Landscape Architecture, J. Corner (ed.). New York: Princeton Architectural Press, 1999, p. 44-57. ISBN 978-1568981796

24. Hargreaves, G. Large parks: A designer's perspective. Large parks, J. Czerniak, G. Hargreaves (eds.). New York: Princeton Architectural Press, 2007, p. 121-174. ISBN 1-56898-624-6

25. Reed, C. The agency of ecology. Ecological Urbanism, M. Mostafavi; G. Doherty (eds.). Baden: Lars Müller Publishers, 2010, p. 324-329. ISBN: 978-3037781890

26. Davoine, G. In conversation with Michel Desvigne: Intermediate landscapes. Landscape Urbanism: A Manual for the Machinic Landscape, M. Mostafavi, C. Najle (eds.). London: Architectural Association, 2003, p. 82-89. ISBN 1-90290230-0

27. Pollak, L. Matrix landscape: construction of identity in the large park. Large parks, J. Czerniak, G. Hargreaves (eds.). New York: Princeton Architectural Press, 2007, ISBN 1-56898-624-6

28. Forman, R. T. T., Wilson, E. O. Land mosaics: The ecology of landscapes and regions. New York: Cambridge University Press, 1995. 656 pp. ISBN: 978-0521479806

29. Wu, J. Key concepts and research topics in landscape ecology revisited: 30 years after the Allerton Park workshop. Landscape Ecology, 2013, Vol. 28(1), p. 1-11. https://doi.org/10.1007/s10980-012-9836-y

30. Czerniak, J. Looking back at landscape urbanism: Speculations on site. The Landscape Urbanism Reader, C. Waldheim (ed.). New York: Princeton Architectural Press, 2006, p. 105-124. ISBN: 978-1568984391

31. Waltner-Toews, D., Kay, J., Lister, N.-M. The ecosystem approach: Complexity, uncertainty, and managing for sustainability. New York Chichester: Columbia University Press, 2008. 408 pp. ISBN: 9780231132510

32. Kay, J., Regier, H. A., Boyle, M. et. al. An ecosystem approach for sustainability: addressing the challenge of complexity. Futures, 1999, Vol. 31(7), p. 721-742. https://doi.org/10.1016/S0016-3287(99)00029-4

33. Carpenter, S, Walker, B., Anderies, J. M., et. al. From metaphor to measurement: Resilience of what to what? Ecosystems, 2001, Vol. 4(8), p. 765-781. https://doi.org/10.1007/s10021-001-0045-9 
34. Folke, C., Carpenter, S. R., Walker, B., et. al. Resilience thinking: Integrating resilience , adaptability and transformability. Ecology and Society, 2010, Vol. 15(4): 20. [available at:] http://www.ecologyandsociety. org/vol15/iss4/art20/

INFORMATION ABOUT AUTHOR:

Paula Gomes da Silva has a PhD in Landscape Architecture from the University of Lisbon. She is a lecturer at the University of Algarve. She is responsible for the undergraduate degree of landscape architecture at the University of Algarve. She also teaches several courses in Landscape architecture (BA and MA levels). She is a member of LEAF Research Centre of University of Lisbon in the thematic line "Blue and green infrastructures" and the Landscape and Construction Heritage Centre of the University of Algarve and of LEAF/U. Lisboa, CEPAC/U. Algarve, e-mail: pgsilva@ualg.pt

Kopsavilkums. Ekologiija ir būtiski veicinājusi ainavu arhitektūras att̄̄stību. Ekologijai joprojām ir l̦oti nozīmīga loma ainavu arhitektūras praksē. Tomēr vairāki autori ir noteikuši ierobežojumus zināšanu nodošanas procesam un tā piemērošanai ainavu dizaina speciālistiem. Lìdz ar to, pētījumā analizēta teorētiskā kritika ainavu dizaina jomā laika posmā no 1999. līdz 2010. gadam, identificējot to kā mantojumu ekoloǵisko koncepciju izmantošanā un dizaina stratẹgiju izstrādē. Pētījumā aptverti un analizēti 15 ainavu arhitektūras dizaina teoriju dokumenti un materiāli, tostarp grāmatas, nodaļas un esejas, kas galvenokārt saistītas ar urbanizētu ainavu. Pētījuma mērḳis: identificēt izmantotos ekolog̣iskos jēdzienus un virzienu, kādā tie strādāja ainavu dizainā. Iegūto materiālu analīzē tika fiksēti 23 ekoloǵiskie jēdzieni un vairāki priekšlikumi to ieviešanai. Identificētie jēdzieni ietilpst divās tendencēs: formas un procesa sakārtošana un dizaina jauda. Rakstā tiek apgalvots, ka teorētiskais ieguldījums, kas veikts laikā no 1999. līdz 2010. gadam, norāda uz nozīmīgām ekologiskām darb̄̄bām, no kurām var izpētīt inovatīvas dizaina pieejas, kas integrē ekologíju. 